\title{
The Assessment of Green Water Based on the SWAT Model: A Case Study in the Hai River Basin, China
}

\author{
Kui Zhu ${ }^{1}$, Zibo Xie ${ }^{1}$, Yong Zhao ${ }^{2, *}$ (D) , Fan Lu ${ }^{2, *}$, Xinyi Song ${ }^{1}, \mathrm{Lu} \mathrm{Li}^{3}{ }^{(\mathbb{D})}$ and Xiaomeng Song ${ }^{1}$ \\ 1 School of Resources and Earth Science, China University of Mining and Technology, Xuzhou 221116, Jiangsu, \\ China; kzhu@cumt.edu.cn (K.Z.); shuiwenxiezibo@cumt.edu.cn (Z.X.); lglrwjx@gmail.com (X.S.); \\ xmsong@cumt.edu.cn (X.S.) \\ 2 State Key Laboratory of Simulation and Regulation of Water Cycle in River Basin, China Institute of Water \\ Resources and Hydropower Research, Beijing 100038, China \\ 3 Uni Research Climate, Bjerknes Centre for Climate Research, Jahnebakken 5, 5007 Bergen, Norway; \\ lu.li@uni.no \\ * Correspondence: zhaoyong@iwhr.com (Y.Z.); lufan@iwhr.com (F.L.); \\ Tel.: +86-10-6878-1617 (Y.Z.); +86-10-6878-1950 (F.L.)
}

Received: 12 April 2018; Accepted: 14 June 2018; Published: 16 June 2018

\begin{abstract}
Green water accounts for two-thirds of precipitation, and the proportion could be even higher in dry years. Conflicts between water supply and demand have gradually become severe in the Hai River Basin (HRB) due to the socio-economic development. Thus, the exploitation and the utilization of green water have attracted increasing attention. By gathering the related hydrological, meteorological, and geographic data, the spatiotemporal distribution of green water in HRB and the impacts of land use types on green water are analyzed based on the SWAT (Soil and Water Assessment Tool) model in this study. Furthermore, three new indices are proposed for evaluation, including the maximum possible storage of green water (MSGW), the consumed green water (CGW), and the utilizable green water (UGW). The results show that (1) the MSGW is relatively low in plain areas and its spatial distribution is significantly associated with the soil type; (2) according to the evaluation results of CGW and UGW in HRB, a further improvement of utilization efficiency of green water could be achieved; (3) in general, the utilization efficiency of precipitation in farmlands is higher than other land use types, which means that the planting of appropriate plants could be helpful to enhance the utilization efficiency of green water. Our results summarize the spatiotemporal distribution of green water resource and provide a reference for water resources management in other water-short agricultural areas.
\end{abstract}

Keywords: maximum possible storage of green water; consumed green water; utilizable green water; water-deficient

\section{Introduction}

Water is an indispensable natural resource for human beings, and it plays important roles in maintaining the sustainable development of the ecosystem and the stability of manufacturing activity [1,2]. Falkenmark proposed that water is separated in two main types: blue water and green water [3]. Blue water includes surface and groundwater runoff, and green water refers to precipitation that is stored in the root zone of the soil and that evaporates, transpires, or gets incorporated by plants. Traditional methods for evaluating water resources were mainly focused on blue water, whereas green water has been overlooked because its availability is limited (it cannot be directly exploited). However, green water is the principle water source that sustains the whole terrestrial ecosystem, including crops, grasslands, and forests, which guarantee the food security for people around the world [4-7]. 
About $60 \%$ of food production in the world depends on green water, and almost all meat products of animal husbandry and forest products rely on green water [8]. In the components of global annual average water footprint, green water footprint (consumption of green water) and blue water footprint (consumption of surface and ground water) account for $74 \%$ and $11 \%$, respectively [9]. With such high contribution to food production, green water is a vital resource that requires more attention in terms of efficient utilization. Therefore, it is essential to study and evaluate green water.

Since green water was first proposed, it has been continually studied and its utility has improved. Falkenmark proposed that green water contains two parts: green water flow and the green water storage [10]. Rockström further divided green water flow into the productive part (the actual transpiration), which impacts plant biomass, and the non-productive part (the actual evaporation) [11]. In recent year, more research has been done on assessment of soil water resources and the corresponding evaluation indices system has been established [12,13]. The green water has gradually attracted attention as a significant resource in hydrology research and water resources assessment [5,14-16]. For example, some studies focused on the quantity and spatiotemporal distribution of green water [15-19], numerous studied have also been done on the impacts of land use types on green water [20-22]. Furthermore, the studies on water footprint provides a reference for the green water resource research [23,24]. These studies were particularly useful for developing an overview of the green water resources status and helped to find out areas where further analysis may be indispensable. Green water flow and green water storage were selected as the main evaluation indicators in those previous studies. However, these indicators may not be clear enough for the available water evaluation in practical applications. For instance, it is obvious that not all the soil water content could be absorbed by plants, therefore, the use of green water storage to estimate the quantity of green water resources is not reliable in a way and may even mislead the water resources management policy.

In this study, three new indicators (MSGW, CGW, and UGW) are proposed for the appraisal of the green water resource more holistically. The depth of plant roots was considered when analyzing the MSGW (the maximum possible storage of green water), which represented the theoretical utilization potential of green water in a watershed. Evaporation was regarded as the unproductive part of numerous studies $[23,25,26]$. However, evaporation and transpiration are closely interlinked hydrologic processes, and it is supposed that evaporated water has the potential to be partly used for food production [27]. Therefore, the total actual evapotranspiration in farmlands, grasslands, and woodlands was considered to be consumed green water (CGW) in this study. Evapotranspiration from the urban area and water body cannot be utilized and has been defined as non-utilized green water (NGW). CGW provide the consumption status of green water. To quantitatively evaluate the development and utilization value of green water storage, UGW (utilizable green water) was proposed to represent the part of green water, which can still be utilized by plants.

Agricultural droughts occur in almost all areas in the world. The problem is usually more severe because the potential evapotranspiration is considerably higher than precipitation in a dryland farming area $[28,29]$. The Hai River Basin (HRB) is one of the main agricultural areas in China. However, problems of agricultural drought existed, and the water consumption was mainly provided by groundwater in HRB [30]. With the development of the urban construction and agriculture, the basic demand for water kept increasing, which caused a serious overdrawing of the shallow groundwater. Many scholars have paid more attention to the precipitation, the surface water, and the groundwater in HRB than the green water [31-34]. Since green water is the main water resource consumed, this paper aimed at making a comprehensive assessment of the green water with the new indicators (MSGW, CGW, and UGW) in an agricultural region that is facing a water shortage problem. By using the SWAT (Soil and Water Assessment Tool) model, the hydrological cycle processes for the period of 1995-2004 in HRB were simulated. The evaluation of green water could provide practical and efficient references for water management. 


\section{Materials and Methods}

\subsection{Study Area}

The study area is the Hai River basin with a drainage area of $3.18 \times 10^{5} \mathrm{~km}^{2}$, located in a semi-humid zone in northern China $\left(35^{\circ} \mathrm{N}-43^{\circ} \mathrm{N}\right.$ and $\left.112^{\circ} \mathrm{E}-120^{\circ} \mathrm{E}\right)$. To make it convenient for management, the Hai River Water Conservancy Commission divided the whole basin into 15 hydrological regions according to the topography, distribution of river net and administrative region (Figure 1) [35]. The mean annual precipitation in HRB is $539 \mathrm{~mm}$ with a high monthly variability. It is rainless in autumn and winter and dry in spring with a high evaporation rate, which leads to frequent droughts. However, it is warm and wet in summer because of the abundant precipitation and rainstorms. The mean annual temperature is $7.8-13.5^{\circ} \mathrm{C}$ and the relative humidity is $50 \%-70 \%$. The mean annual land evaporation and water surface evaporation in the study area are $500 \mathrm{~mm}$ and $1100 \mathrm{~mm}$, respectively.

Approximately $22 \%$ of total rainfall runoff is the water consumption in the watershed, and more than $60 \%$ of it is used in agricultural areas. HRB needs water from other river basins through the water diversion project to satisfy the water requirements during the past few years [30]. Maize and winter wheat are the main crops in HRB [30], the accurate quantification and spatiotemporal distribution of green water could potentially facilitate the selection of more appropriate copping patterns in HRB, to reduce evapotranspiration and utilize green water more efficiently. Furthermore, it could achieve the goal of reducing water consumption from surface water and groundwater, which is used for agricultural production, and alleviating the problem of the water shortage.

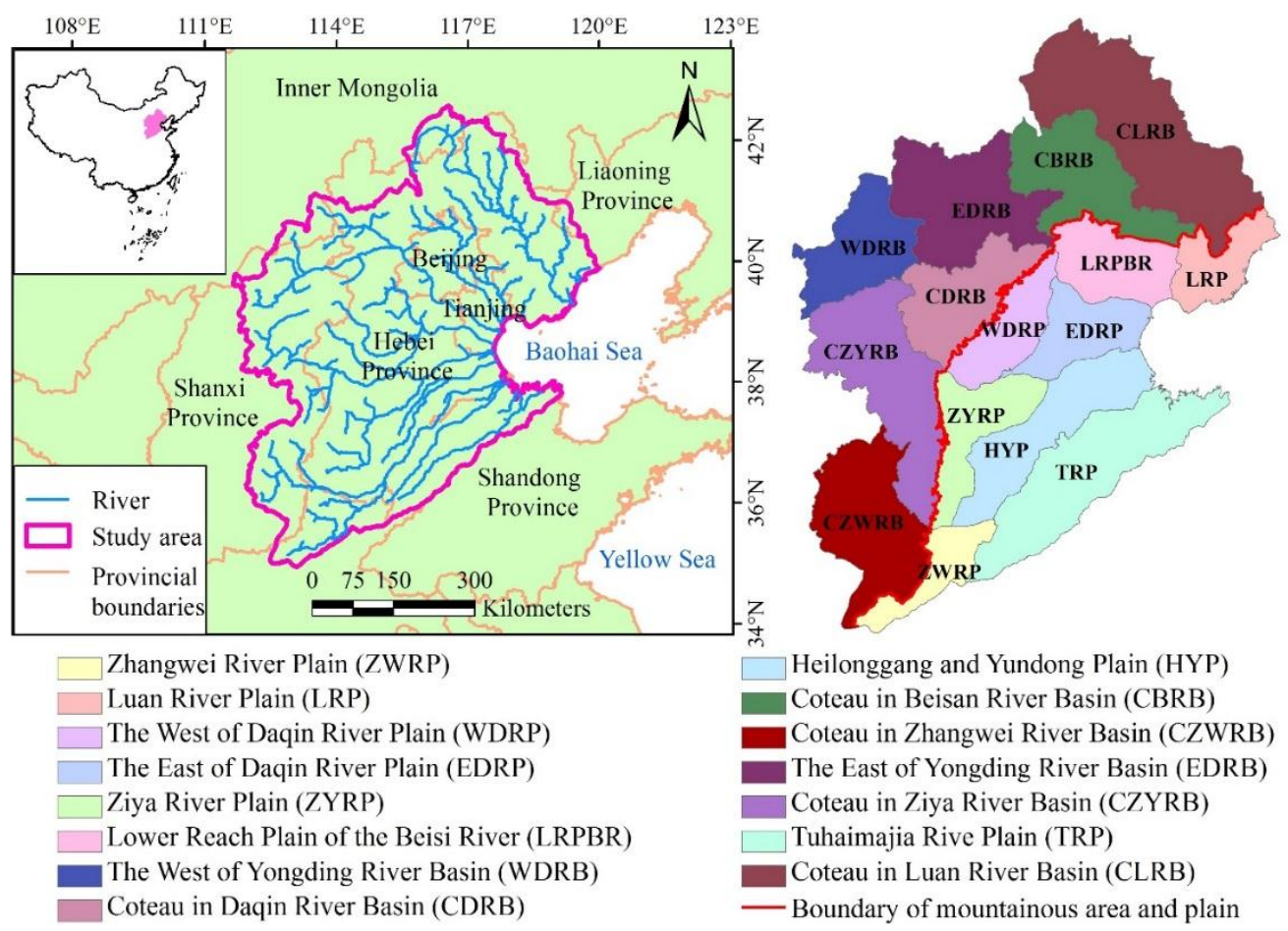

Figure 1. The location of the Hai River basin (HRB) and its hydrological regions.

\subsection{Data}

The daily meteorological data from 43 meteorological stations (including air temperature, wind speed, solar radiation, and relative humidity) and precipitation data from 216 stations in the study region (1995-2004), were provided by the China Meteorological Administration (CMA) (http://www.cma.gov.cn/). The data is complete in most stations, dozens of precipitation stations, the 
data series were completed by using the data in adjacent station. The data quality check haven been made by CMA (http:/ / data.cma.cn/). The hydrological data from 9 stations were collected from the Hai River Water Conservancy Commission (http:/ / www.hwcc.gov.cn/). These data are the fundamental inputs for the SWAT model and served as the driving force for other simulation processes in this model. The distribution of these stations is shown in Figure 2. The soil data $(1: 1,000,000)$ were provided by the Institute of Soil Science of the Chinese Academy of Sciences. Figure 3a shows the distribution of different soil types, which can be divided into 27 categories. The soil classification is based on the Genetic Soil Classification of China (GSCC) [36]. Since the soil particle graded standard in GSCC differs from the standard in the SWAT model (the standard of United States Department of Agriculture), the standard conversion was completed by using the cubic spline interpolation [37]. Then, the soil parameters (such as the saturated hydraulic conductivity and bulk density) were estimated on the basis of the soil texture (the proportion of clay, silt, sand, and rock) using the Soil Water Characteristics Hydraulic Properties Calculator [38]. The DEM (Digital Elevation Model) data was collected from the Data Cloud of Chinese Academy of Sciences (http:/ / www.csdb.cn/) and it was extracted from the SRTM DEM (Shuttle Radar Topography Mission Digital Elevation Model) with a resolution of $90 \mathrm{~m}$. The land use data in 2004 with a spatial resolution of $250 \mathrm{~m} \times 250 \mathrm{~m}$ were provided by Institute of Remote Sensing and Digital Earth of the Chinese Academy of Sciences. The source data is the Landsat TM/ETM (Thematic Mapper/Enhanced Thematic Mapper) remote sensing data and the land use data was generated through artificial visual interpretation. The land use classification is based on the relevant government standard in China [39]. The dominant types of land use are farmland, woodland, and grassland, which collectively account for $94 \%$ of the study region (Figure 3b).

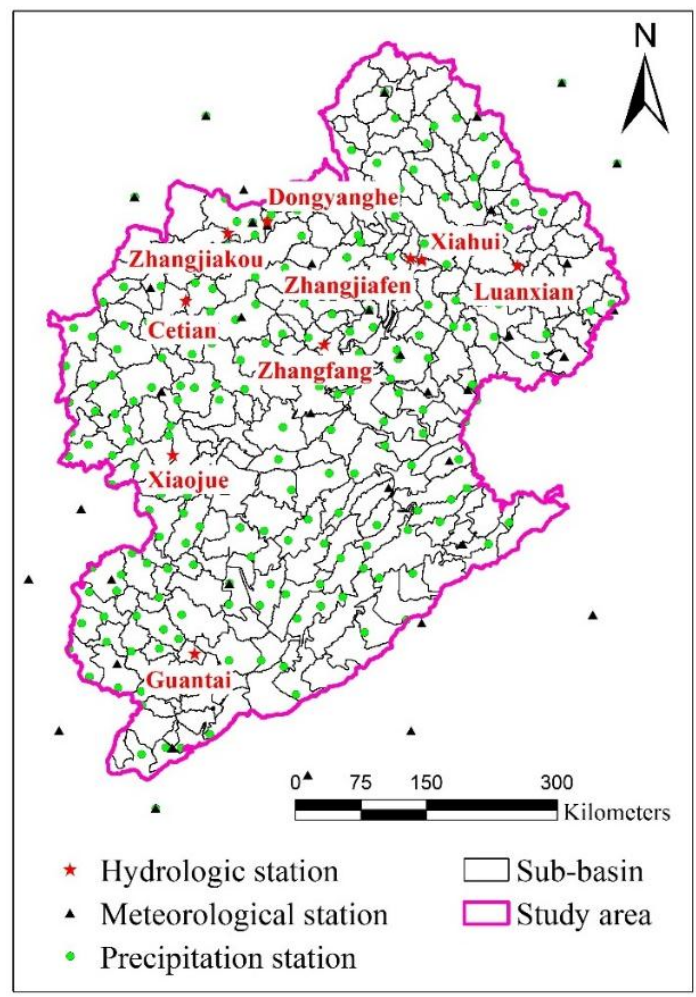

Figure 2. The distribution of the river net, sub-basins, and the locations of meteorological, precipitations and hydrologic stations which were used in the model simulations in HRB. 


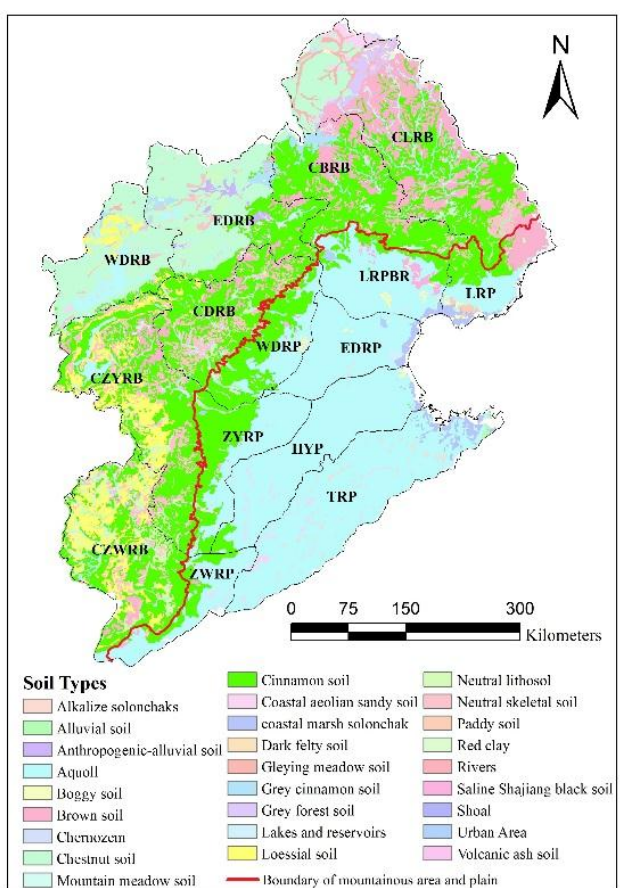

(a)

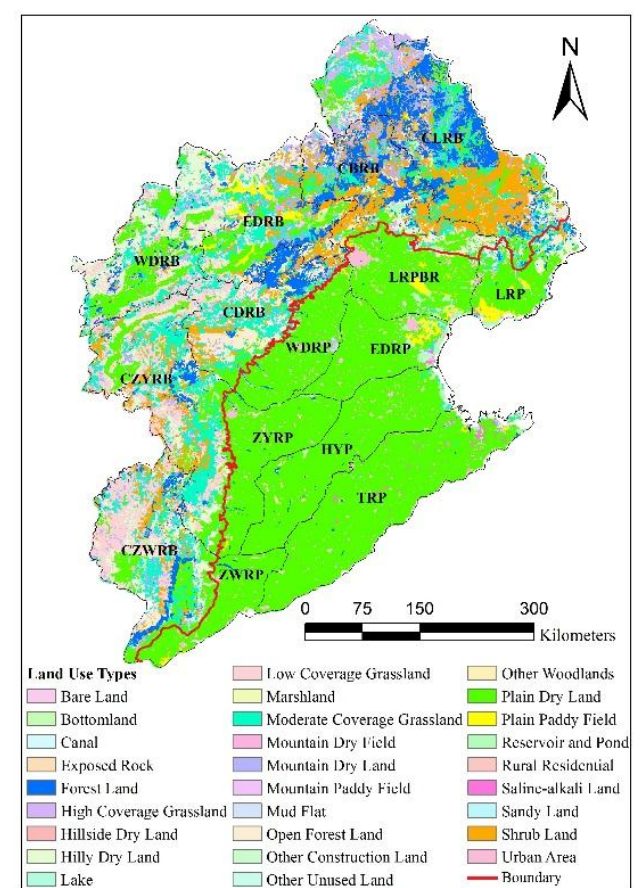

(b)

Figure 3. The spatial distribution of soil types (a) and land use types (b) in HRB.

\subsection{Methodology}

\subsubsection{SWAT Model and Simulation Setup}

The SWAT model has been widely applied in studies at different regions because of its high precision and wide applicability [40]. The SWAT simulator version 2000 and its ArcView interface [41-43] were used in this study. In SWAT modeling, the study basin is divided into many sub-basins based on the digital elevation model (DEM) data. Then, each sub-basin can be further subdivided into several hydrologic response units (HRU) which consist of similar land use types, soil, and slope characteristics [44]. There are 283 sub-basins in total and 2100 HRUs in the Hai river basin for SWAT modeling. Different hydrological components, for example, evapotranspiration, infiltration, and water surface evaporation are calculated in each HRU. Eventually, it obtains the hydrological variables, such as evapotranspiration and surface runoff, in each sub-basin. The modeling process adopts the water balance method, which is expressed as follows:

$$
S W_{t}=S W_{0}+\sum_{i=1}^{t}\left(R_{d a y, i}-Q_{s e r f, i}-E_{i}-W_{s e e p, i}-Q_{g w, i}\right)
$$

where $S W_{t}$ is the final soil water content $(\mathrm{mm}), S W_{0}$ is the initial soil water content on day $i(\mathrm{~mm}), t$ is the time (day), $R_{\text {day }, i}$ is the amount of precipitation on day $i(\mathrm{~mm}), Q_{\text {surf }, i}$ is the amount of surface runoff on day $i(\mathrm{~mm}), E_{i}$ is the amount of evapotranspiration on day $i(\mathrm{~mm}), W_{\text {seep }, i}$ is the amount of water entering the unsaturated zone from the soil profile on day $i(\mathrm{~mm}), Q_{g w}, i$ is the amount of return flow on day $i(\mathrm{~mm})$.

There are multiple options for runoff generation and evapotranspiration estimation, which are provided in the SWAT model. According to the previous research [31,45], the soil conservation service curve number method and the Priestley-Taylor method were applied to the runoff generation and evapotranspiration calculation in this study, respectively. The monthly assessment results of green water have practical significance to guide the agricultural production. Therefore, the time step of SWAT modeling is monthly in the study. 
Because only about $6.3 \%$ areas were irrigated in the mountainous area [30], the irrigation has been ignored during model simulation. Due to the lack of exactly data about irrigation time and amount for irrigation zone in plain area, the irrigation in study area was triggered by a soil water deficit threshold [46]. In agricultural HRUs, the soil water deficit threshold was defined as $75 \%$ of the soil field capacity according to relevant studies $[47,48]$.

A sensitivity analysis can dramatically reduce the number of parameters in model calibration. By using the LH-OAT (Latin hypercube one-factor-at-a-time) method, Sun selected the sensitive parameters for the mountains area and plain area in HRB, respectively [49]. Wang chose four main parameters to calibrate the SWAT model in HRB with observed runoff data [31]. Based on the former research, 12 sensitivity parameters were identified and selected for further model calibration of the sub-basins in this study (Table 1). Then, the final model calibration has been done by using SUFI-2 (sequential uncertainty fitting algorithm) method [50]. The Nash-Sutcliffe efficiency coefficients (NS) and the coefficient of determination $\left(R^{2}\right)$ are chosen as the indices for the model calibration and validation in the study [51]. Both are as much closer to be 1 as better, which means a good fitting result. The model performance is considered to be satisfactory if the NS $>0.5$, according to the model evaluation guidelines for watershed simulations $[52,53]$.

Table 1. The parameters used in the model calibration and validation.

\begin{tabular}{lll}
\hline Parameter & Description & Maximum Theoretical Range \\
\hline ALPHA_BF & Base flow alpha factor (day) & $0-1$ \\
\hline BLAI & Maximum potential leaf area index & $0-12$ \\
\hline CANMX & Maximum canopy index $\left(\mathrm{mm} \mathrm{H}{ }_{2} \mathrm{O}\right)$ & $0-100$ \\
\hline CH_K2 & Hydraulic conductivity in main channel alluvium $(\mathrm{mm} / \mathrm{h})$ & $0-150$ \\
\hline CN2 & The SCS (soil conservation service) runoff curve number & $30-95$ \\
\hline EPCO & Plant evaporation compensation factor & $0.01-1$ \\
\hline ESCO & Soil evaporation compensation factor & $0.01-1$ \\
\hline GW_DELAY & Groundwater delay (day) & $0-500$ \\
\hline GWQMN & $\begin{array}{l}\text { Threshold depth of water in the shallow aquifer required for } \\
\text { return flow to occur (mm) }\end{array}$ & $0-5000$ \\
\hline RCHRG_DP & Groundwater recharge to the deep aquifer & $0-1.0$ \\
\hline REVAPMN & $\begin{array}{l}\text { Threshold depth of water in the shallow aquifer for "revap" } \\
\text { or percolation to the deep aquifer to occur (mm) }\end{array}$ & $0-500$ \\
\hline SOL_AWC & Available soil water content (mm/mm) & $0-0.5$ \\
\hline
\end{tabular}

\subsubsection{Evaluation Methods}

Previous studies of evaluating green water were mainly focused on the green water flow (actual ET) and the green water storage (that is, soil water) [15-19]. To conduct a more comprehensive analysis of the quantity and distribution of green water, three evaluation indices are introduced in this study.

1. The maximum possible storage of green water (MSGW)

The soil moisture content could range from standard moisture content to the saturation moisture content. In general, it is widely recognized that the soil moisture could only be absorbed by plants when it ranges between field capacity $(F C)$ and permanent wilting percentage $\left(W_{p}\right)$. This kind of soil moisture is defined as the available water capacity $(A W C)$. The maximum possible storage of green water can be calculated by using $A W C$ and the corresponding depth of soil layer $(D)$, where $D$ is determined by the depth of the plant roots.

$$
A W C_{i}=F C_{i}-W_{P, i}
$$




$$
W_{m s}=\sum_{i=1}^{n} A W C_{i} \times D_{i}
$$

where $W_{m s}$ is the maximum possible storage of green water, $A W C_{i}(\mathrm{~mm})$ is the available water capacity in soil layer $i, F C_{i}(\mathrm{~mm})$ is the field capacity in soil layer $i, W_{P, i}$ is the permanent wilting percentage in soil layer $i(\mathrm{~mm}), D_{i}$ is the depth of soil layer $i(\mathrm{~mm})$.

2. Consumed green water (CGW)

The land use types have been divided into farmland, grassland, woodland, urban area, and surface water body. In general, evapotranspiration from urban areas and water bodies cannot be utilized, which are usually regarded as nonproductive green water. This part of evapotranspiration has been defined as non-utilized green water (NGW) in this paper, and the rest of the evapotranspiration refers to the consumed green water (CGW). The formula is defined as the following:

$$
W_{c}=\sum_{i=1}^{n} E_{i}+\sum_{i=1}^{n} T_{i}
$$

where $W_{c}$ is the consumed green water $(\mathrm{mm}), T_{i}$ is the transpiration in different plants species $(\mathrm{mm})$, and $E_{i}$ is the evaporation between plants in the different plant species (mm).

\section{Utilizable green water (UGW)}

The utilizable green water is calculated according to the permanent wilting percentage $\left(W_{p}\right)$ and soil water content $(S W)$, and the formula is expressed as follows:

$$
W_{u}=\sum_{i=1}^{n} S W_{i}-W_{p, i}
$$

where $W_{u}$ is the utilizable green water, $S W_{i}$ is the soil water content in soil layer $i(\mathrm{~mm}), W_{P, i}$ is the permanent wilting percentage in soil layer $i(\mathrm{~mm})$.

Blue water can directly be obtained from the simulation results [40]. The three new indices represent the storage volume, utilization state, and the exploitation potential of green water. After the soil moisture parameters of the different soil types (including the available water capacity $(A W C)$, field capacity $(F C)$, permanent wilting percentage $\left(W_{p}\right)$, and soil water content $\left.(S W)\right)$ have been calculated by the SWAT model, we can obtain the distribution of the MSGW and UGW in each sub-basin through area weighting. Using the same method, the CGW in a sub-basin equals the difference between the evapotranspiration (ET) and NGW.

\section{Results}

\subsection{Analysis of the Simulation Results}

\subsubsection{Model Calibration and Validation}

The model calibration was divided into two parts in the HRB according to the locations of sub-basin and its runoff data quality. For the sub-basins in the mountainous area with relatively low human impacts, the model calibrations are based on the monthly runoff. The model was calibrated from 1995 to 1999 and validated from 2000 to 2004 for the mountainous area based on the observed monthly runoff data. The final range of the parameters after model calibration are shown in Table 2 . The NS $>0.65$ and $R^{2}>0.8$ for each discharge station during calibration are shown in Table 3 . The model was validated using the calibrated parameters and the results are also satisfactory, as shown in Table 3 . The monthly runoff at Zhangjiakou station and Dongyanghe station are further illustrated in Figure 4. 
Table 2. The value range of the sensitive parameters in the mountainous area after model calibration.

\begin{tabular}{|c|c|c|c|c|c|c|c|}
\hline \multirow{2}{*}{ Parameter } & \multicolumn{7}{|c|}{ Final Range of Parameters After Model Calibration } \\
\hline & CLRB & CBRB & EDRB & WDRB & CDRB & CZYRB & CZWRB \\
\hline ALPHA_BF & $0.05-0.10$ & $0.10-0.16$ & $0.10-0.14$ & $0.10-0.15$ & $0.06-0.10$ & $0.08-0.15$ & $0.10-0.15$ \\
\hline BLAI* & -0.20 to -0.15 & -0.05 to 0.05 & -0.15 to -0.05 & -0.15 to -0.10 & -0.15 to -0.10 & -0.05 to 0.05 & -0.10 to -0.05 \\
\hline CANMX & $1.2-5.7$ & $1.2-5.8$ & $1.3-6.0$ & $0.8-4.2$ & $1.5-5.5$ & $0.9-4.5$ & $1.4-5.5$ \\
\hline CH_K2 & 85-100 & 70-95 & $65-85$ & 70-90 & 65-85 & 70-85 & 65-85 \\
\hline CN2 * & -0.20 to -0.15 & -0.10 to 0.05 & -0.25 to -0.15 & -0.20 to -0.15 & -0.15 to -0.10 & -0.25 to -0.20 & -0.15 to -0.10 \\
\hline EPCO & $0.30-0.40$ & $0.20-0.35$ & $0.20-0.30$ & $0.40-0.45$ & $0.35-0.45$ & $0.30-0.40$ & $0.25-0.35$ \\
\hline ESCO & $0.85-0.90$ & $0.80-0.85$ & $0.75-0.85$ & $0.85-0.90$ & $0.80-0.85$ & $0.75-0.85$ & $0.70-0.80$ \\
\hline GW_DELAY & 30-45 & 35-45 & $30-40$ & 31-35 & 35-39 & 40-45 & $42-44$ \\
\hline GWQMN & 40-90 & 50-105 & 20-75 & 60-90 & 45-85 & 55-75 & 60-75 \\
\hline RCHRG_DP & $0.45-0.55$ & $0.40-0.50$ & $0.25-0.35$ & $0.30-0.40$ & $0.35-0.40$ & $0.40-0.45$ & $0.40-0.50$ \\
\hline REVAPMN & $220-270$ & 350-380 & 360-380 & $290-320$ & 330-370 & $360-390$ & $320-350$ \\
\hline SOL_AWC * & $0.10-0.15$ & -0.05 to 0.05 & -0.15 to -0.05 & $0.05-0.10$ & -0.10 to -0.05 & 0.05 to 0.10 & -0.05 to 0.05 \\
\hline
\end{tabular}

* Means a relative change to the initial parameter, the other parameters were replaced by a new value. The locations and full name of the hydrological regions in mountainous area (CLRB, CBRB, EDRB, WDRB, CDRB, CZYRB and CZWRB) have been shown in Figure 1. 
Table 3. The comparison between the observed and simulated monthly discharge of the representative stations in the mountainous hydrological regions during 1995-2004.

\begin{tabular}{cccccc}
\hline \multirow{2}{*}{ Hydrological Region } & Station & \multicolumn{2}{c}{ Calibration (1995-1999) } & \multicolumn{2}{c}{ Validation (2000-2004) } \\
\cline { 3 - 6 } & & $\boldsymbol{N S}$ & $\boldsymbol{R}^{\mathbf{2}}$ & $\mathrm{NS}$ & $\boldsymbol{R}^{\mathbf{2}}$ \\
\hline CLRB & Luanxian & 0.71 & 0.88 & 0.61 & 0.82 \\
CBRB & Zhangjiafen & 0.74 & 0.84 & 0.68 & 0.72 \\
& Xiahui & 0.68 & 0.83 & 0.63 & 0.78 \\
EDRB & Dongyanghe & 0.70 & 0.92 & 0.65 & 0.89 \\
WDRB & Zhangjiakou & 0.69 & 0.96 & 0.65 & 0.90 \\
CDRB & Cetian & 0.74 & 0.82 & 0.70 & 0.77 \\
CZYRB & Zhangfang & 0.70 & 0.86 & 0.64 & 0.72 \\
CZWRB & Xiaojue & 0.79 & 0.89 & 0.70 & 0.82 \\
& Guantai & 0.77 & 0.90 & 0.71 & 0.80 \\
\hline
\end{tabular}

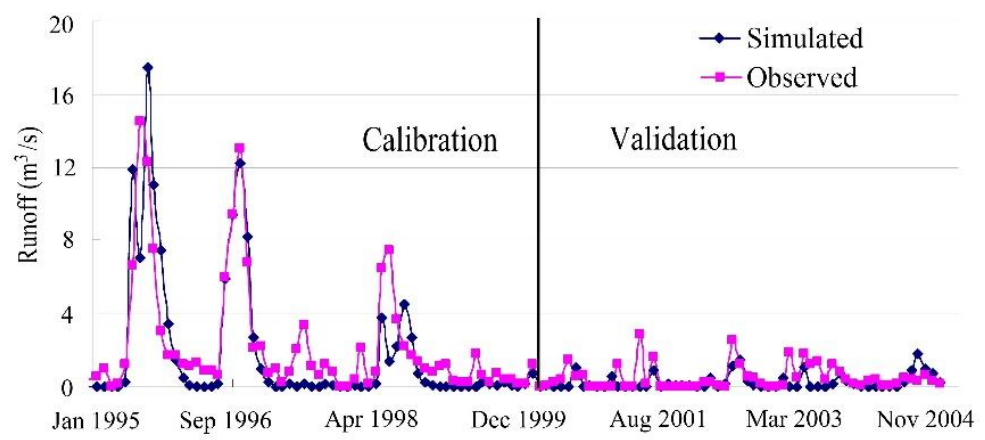

(a)

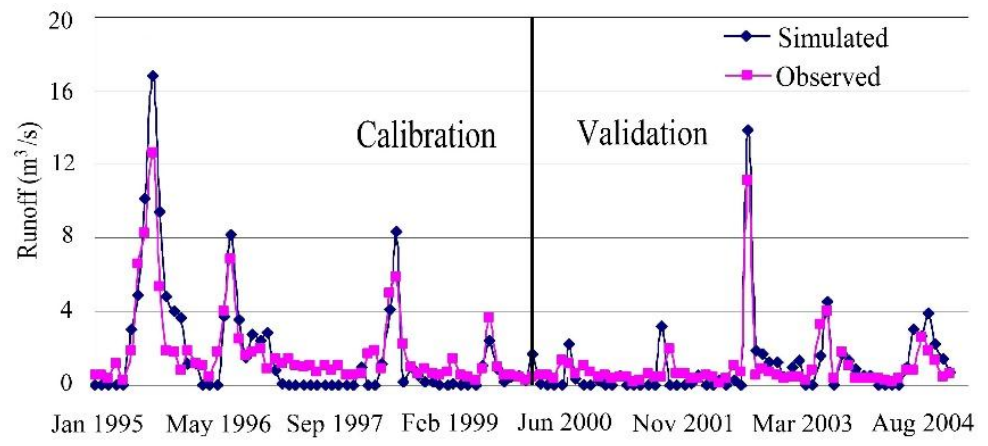

(b)

Figure 4. The comparison of the observed and simulated runoff at the Zhangjiakou station (a) and the Dongyanghe station (b) (1995-2004).

In this study, the yearly quantity of the river discharge into the sea in HRB was used for model calibration for the sub-basins at plain hydrological regions (Tables 4 and 5). The monthly remote sensing ET and simulated ET in the plain hydrological region have been compared (Table 6). The ET data with a resolution of $1000 \mathrm{~m}$ in 2002-2004 were derived from the remote sensing data of MODIS (Moderate-resolution Imaging Spectroradiometer) by using the ETWatch model [54]. The relevant methodology and the results of the remote sensing data processing have already been published, which is based on a separate project by the Institute of Remote Sensing Applications, the Chinese Academy of Sciences [54,55]. The range of NS and $R^{2}$ is $0.60-0.71$ and $0.72-0.83$, respectively, which show that the SWAT model performance works well in ET simulation. The final ranges of the calibrated parameters in the plain areas are shown in Table 4. Based on the calibration and validation, the water balance analysis and green water assessment are implemented in the following section. 
Table 4. The value range of the sensitivity parameters in the plain area after model calibration.

\begin{tabular}{cccccc}
\hline \multirow{2}{*}{ Parameter } & \multicolumn{5}{c}{ Final Range of Parameters After Model Calibration } \\
\cline { 2 - 5 } & LRP & TRP & LRPBR & EDRP and WDRP & HYP and ZYRP and ZWRP \\
\hline ALPHA_BF & $0.20-0.24$ & $0.22-0.25$ & $0.25-0.30$ & $0.25-0.30$ & $0.20-0.25$ \\
BLAI* & -0.05 to 0.15 & -0.05 to 0.05 & $0.05-0.10$ & -0.05 to 0.10 & $0.05-0.15$ \\
CANMX & $0.8-6.0$ & $2.0-5.6$ & $1.2-6.3$ & $0.5-3.5$ & $2.5-4.6$ \\
CH_K2 & $105-120$ & $100-120$ & $115-140$ & $100-115$ & $110-125$ \\
CN2 * & -0.30 to -0.2 & -0.25 to -0.20 & -0.30 to -0.15 & -0.40 to -0.25 & -0.35 to -0.30 \\
EPCO & $0.50-0.75$ & $0.55-0.65$ & $0.65-0.85$ & $0.45-0.60$ & $0.50-0.65$ \\
ESCO & $0.75-0.85$ & $0.70-0.80$ & $0.75-0.85$ & $0.60-0.75$ & $0.75-0.80$ \\
GW_DELAY & $25-35$ & $22-25$ & $25-35$ & $20-30$ & $20-25$ \\
GWQMN & $60-110$ & $70-90$ & $70-100$ & $45-85$ & $75-90$ \\
RCHRG_DP & $0.35-0.45$ & $0.35-0.45$ & $0.45-0.50$ & $0.40-0.50$ & $0.40-0.45$ \\
REVAPMN & $190-220$ & $160-180$ & $130-170$ & $160-190$ & $140-170$ \\
SOL_AWC * & $0.05-0.15$ & $0.10-0.15$ & $0.10-0.15$ & $0.15-0.25$ & $0.05-0.10$ \\
\hline
\end{tabular}

${ }^{*}$ Means a relative change to the initial parameter, the other parameters were replaced by a new value. The locations and full name of the hydrological regions in plain area (LRP, TRP, LRPBR, EDRP, WDRP, HYP, ZYRP and ZWRP) have been shown in Figure 1.

Table 5. The simulated and observed annual river discharge to the sea in the coastal hydrological regions $\left(\mathrm{km}^{3}\right)$.

\begin{tabular}{|c|c|c|c|c|c|c|}
\hline \multirow{2}{*}{$\begin{array}{l}\text { Hydrological } \\
\text { Region }\end{array}$} & \multirow{2}{*}{ Data Type } & \multicolumn{5}{|c|}{ Year } \\
\hline & & 1996 & 1997 & 1998 & 1999 & 2000 \\
\hline \multirow{3}{*}{ LRP } & Simulated & - & 0.37 & 1.42 & 0.29 & 0.39 \\
\hline & Observed ${ }^{a}$ & - & 0.44 & 1.65 & 0.21 & 0.10 \\
\hline & Relative error & - & -0.15 & -0.14 & 0.41 & 2.95 \\
\hline \multirow{3}{*}{ TRP } & Simulated & 2.19 & 0.64 & 1.80 & 0.17 & 0.36 \\
\hline & Observed $^{\mathrm{a}}$ & 2.51 & 0.47 & 1.80 & 0.11 & 0.22 \\
\hline & Relative error & -0.13 & 0.37 & 0.00 & 0.59 & 0.65 \\
\hline \multirow{3}{*}{ LRPBR } & Simulated & 0.23 & 0.12 & 0.49 & 0.37 & 0.43 \\
\hline & Observed ${ }^{a}$ & 0.16 & 0.11 & 0.30 & 0.61 & 0.46 \\
\hline & Relative error & 0.39 & 0.14 & 0.66 & -0.40 & -0.07 \\
\hline \multirow{3}{*}{$\begin{array}{l}\text { EDRP and } \\
\text { WDRP * }\end{array}$} & Simulated & - & 0.38 & 1.89 & 0.11 & 0.27 \\
\hline & Observed ${ }^{a}$ & - & 0.43 & 1.81 & 0.26 & 0.74 \\
\hline & Relative error & - & -0.12 & 0.04 & -0.55 & -0.64 \\
\hline \multirow{3}{*}{$\begin{array}{l}\text { HYP and ZYRP * } \\
\text { and ZWRP * }\end{array}$} & Simulated & - & 0.70 & 3.88 & 0.33 & 0.84 \\
\hline & Observed ${ }^{\mathrm{a}}$ & - & 0.87 & 3.63 & 0.51 & 1.47 \\
\hline & Relative error & - & -0.19 & 0.07 & -0.36 & -0.43 \\
\hline
\end{tabular}

A region name with $\mathrm{a}^{*}$ is an inland hydrological region and it belongs to the same river system with the relative coastal region. The calibration results for those sub-basins in the same hydrological region group (such as EDRP and $\mathrm{WDRP}^{*}$ ) are consistent. For coastal hydrological regions, their discharges are summarized if there are multiple outlets to the sea. ${ }^{a}$ The data was obtained from the Water Resources Bulletin of the Hai River Basin [30].

Table 6. The comparison between the monthly remote sensing ET and simulated ET in the plain hydrological regions during 2002-2004.

\begin{tabular}{|c|c|c|c|c|c|}
\hline Hydrological Region & Area $\left(\mathrm{km}^{2}\right)$ & Average Observed $E T(\mathrm{~mm})$ & Average Simulated $E T(\mathrm{~mm})$ & NS & $R^{2}$ \\
\hline LRP & 10,843 & 43.33 & 38.48 & 0.71 & 0.74 \\
\hline TRP & 31,919 & 45.17 & 42.17 & 0.66 & 0.80 \\
\hline LRPBR & 15,462 & 36.59 & 34.76 & 0.67 & 0.78 \\
\hline HYP and ZYRP and ZWRP & 46,868 & 46.36 & 46.04 & 0.66 & 0.82 \\
\hline
\end{tabular}




\subsubsection{Water Balance Analysis}

In the study, the water balance is analyzed according to three components: precipitation, green water, and blue water. Figure 5 shows the annual precipitation, green water, and blue water in HRB from 1995 to 2004. The annual variation of soil water during the study period (1995-2004) is less than $-2 \mathrm{~mm}$, it indicates that the three components (precipitation, green water, and blue water), which are obtained from the SWAT model simulation, achieves a good balance (nearly all precipitation transforms into blue water and green water). The annual mean green water in HRB is about $365 \mathrm{~mm}$, which accounts for $74 \%$ of the precipitation. In dry years (such as 1997), the proportion can reach up to $90 \%$, it is because the precipitation is more likely to absorbed by soil and utilized by plants instead of formed the river discharge or infiltrated into the aquifer. Therefore, green water plays an important role in the water cycle. The improvement of the utilization efficiency of green water might be one of the keys to relieving the water shortages in HRB.

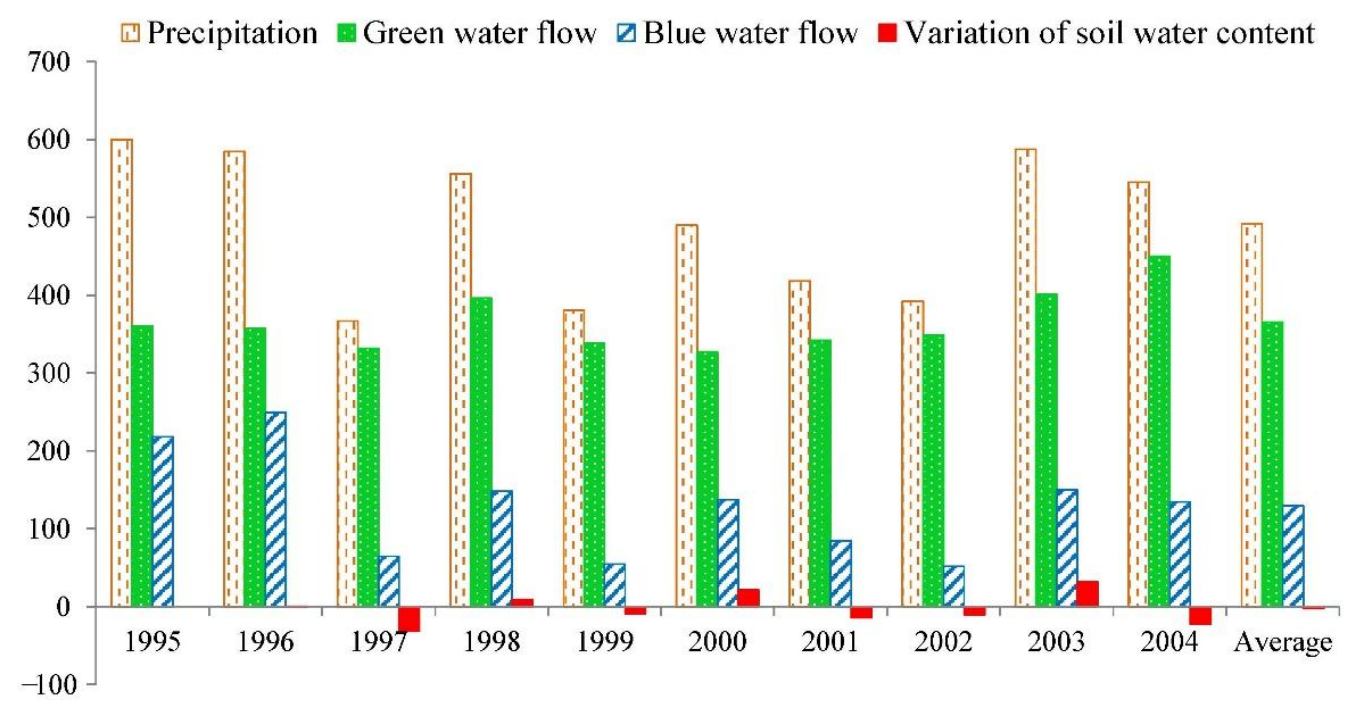

Figure 5. The annual precipitation, blue water, green water, and soil water variation in HRB (1995-2004) (unit: $\mathrm{mm}$ ).

\subsection{Assessment of Green Water}

\subsubsection{Distribution of the Maximum Possible Storage of Green Water}

The average depth of the plant roots in HRB is obtained by calculating the area-weighted average of all the sub-basins. The value is $933 \mathrm{~mm}$ and the maximum possible storage of the green water (MSGW) is $106 \mathrm{~mm}$ (or about $33.2 \mathrm{~km}^{3}$ ). The spatial distribution of the MSGW is shown in Figure 6. According to Equation (3), the main influencing factors of MSGW are the depth of the plant roots and soil moisture capacity. From Figures 3 and 6, we can see that the distribution of MSGW has a significant correlation with soil types. Loessial soil is the dominating soil type in the upper reaches of the Zhangwei River (CZWRB) and the Ziya River (CZYRB). The field capacity $(F C)$ and permanent wilting percentage $(W p)$ are $157.6 \mathrm{~mm}$ and $40.9 \mathrm{~mm}$, respectively. According to Equation (2), the available water capacity is $116.7 \mathrm{~mm}$. Cinnamon soil is the dominating soil type in the piedmont plain areas except for the upper reaches of Luan River (CLRB), which is mixed with brown soil. The AWC in cinnamon soil and brown soil are $110.5 \mathrm{~mm}$ and $111.7 \mathrm{~mm}$, respectively. Due to a low $A W C$ of $95.1 \mathrm{~mm}$ and a shallow depth of plant roots, the MSGW in the plain area is lower than other areas. The upper reaches of Yongding River, including hydrological regions of the West of Yongding River basin (WDRB) and the East of Yongding River basin (EDRB), locates at the west part of HRB. The FC over there is $198.9 \mathrm{~mm}$ and WP 
is $98.7 \mathrm{~mm}$, which is higher than that of its surrounding area. However, the $A W C$ is comparatively low $(100.1 \mathrm{~mm})$, indicating that the MSGW is relatively poor in these areas.

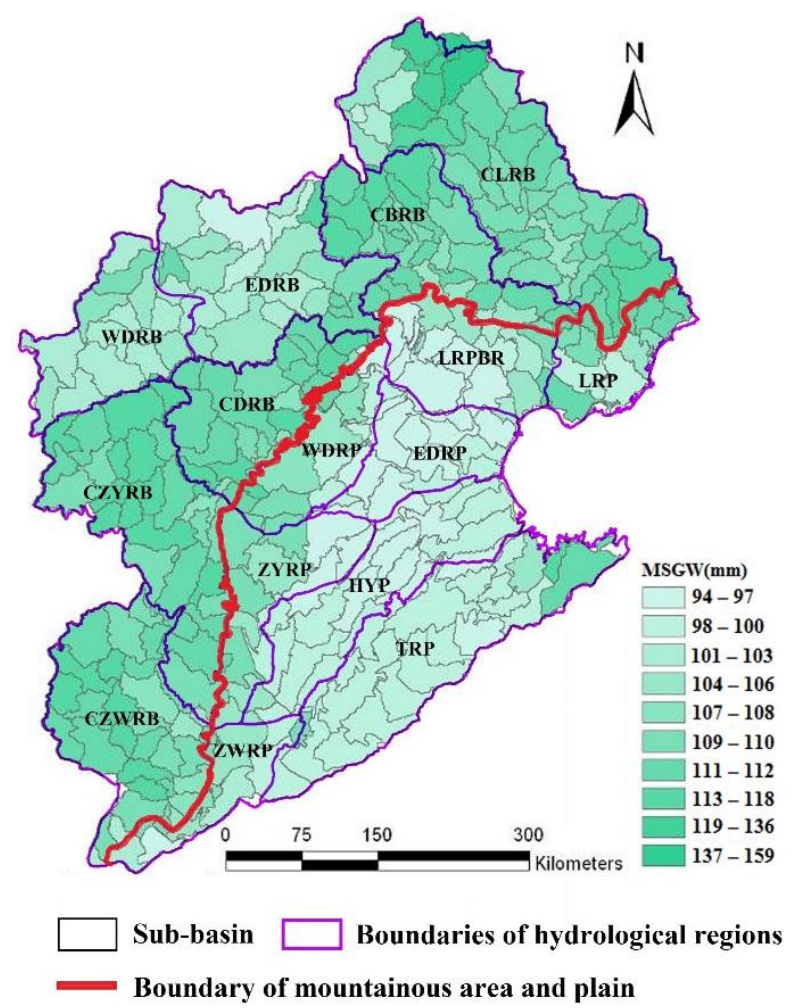

Figure 6. The spatial distribution of the maximum possible storage of green water (MSGW) in HRB.

\subsubsection{Analysis of the Consumed Green Water and Utilizable Green Water}

The consumed green water (CGW) and the utilizable green water (UGW) in HRB are calculated based on Equations (4) and (5). As is shown in Figure 7, the annual mean value of blue water in HRB is $129 \mathrm{~mm}$, which accounts for $26.2 \%$ of the precipitation. The annual mean of CGW and UGW are $339 \mathrm{~mm}$ and $27 \mathrm{~mm}$, respectively. The results show that green water accounts for $74.1 \%$ of the precipitation. The sum of blue and green water components is $100.3 \%$. This is because the annual mean variation of the soil water content is $-1.7 \mathrm{~mm}$ (accounts for the $-0.3 \%$ of the precipitation). Therefore, it is unlikely to remit the water shortage in HRB by the integrated management of blue water. How to properly use the green water will become one of the keys to solving conflicts between the supply and demand of water in the HRB. According to the quantitative analysis, the annual mean value of UGW is $27 \mathrm{~mm}$, which means that the green water resource in the whole HRB still has not been fully utilized. The UGW is still higher than $10 \mathrm{~mm}$, even in dry years (that is, 1997, 1999, and 2002). 


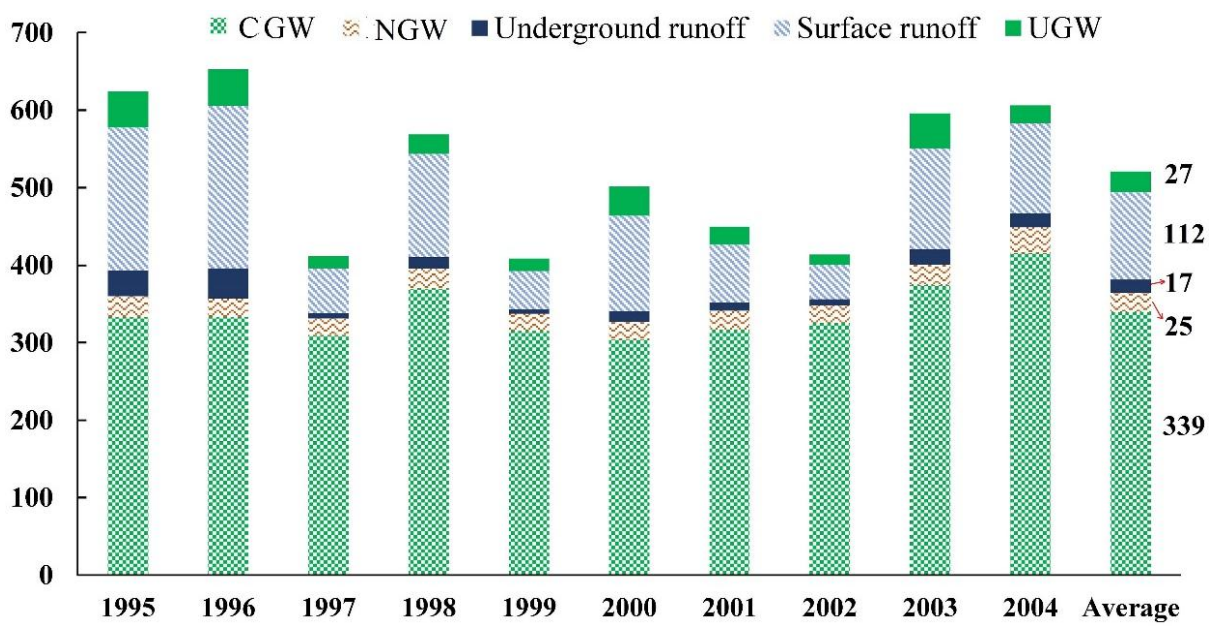

Figure 7. The components of green water and blue water in HRB (1995-2004) (unit: mm).

The distribution of green water is further analyzed and shown in Figure 8a,b, from which we can see that the CGW and UGW in the HRB have a similar spatial pattern, which indicates that the green water is abundant in CZWRB, CZYRB and CLRB. These areas have comparatively large values of CGW and UGW. Thus, there is a huge potential to boost the utilization efficiency of green water. The evaporation from urban areas cannot be utilized, and most of cities and towns are distributed in the plain areas. This helps to explain why the value of CGW is relatively low in those areas. A comparatively large amount of CGW $(350 \mathrm{~mm})$ can be observed in the East of the Yongding River Basin (EDRB), but the UGW is close to zero in this area. This indicates that the green water in the EDRB has been fully utilized in transpiration. The green water is relatively poor in the plain areas and particularly in the piedmont plain, where the CGW is less than $350 \mathrm{~mm}$ and the UGW is less than $40 \mathrm{~mm}$. Considering that most of the cultivated lands are distributed in these areas, the green water cannot meet the requirements of crops, and irrigation is indispensable.

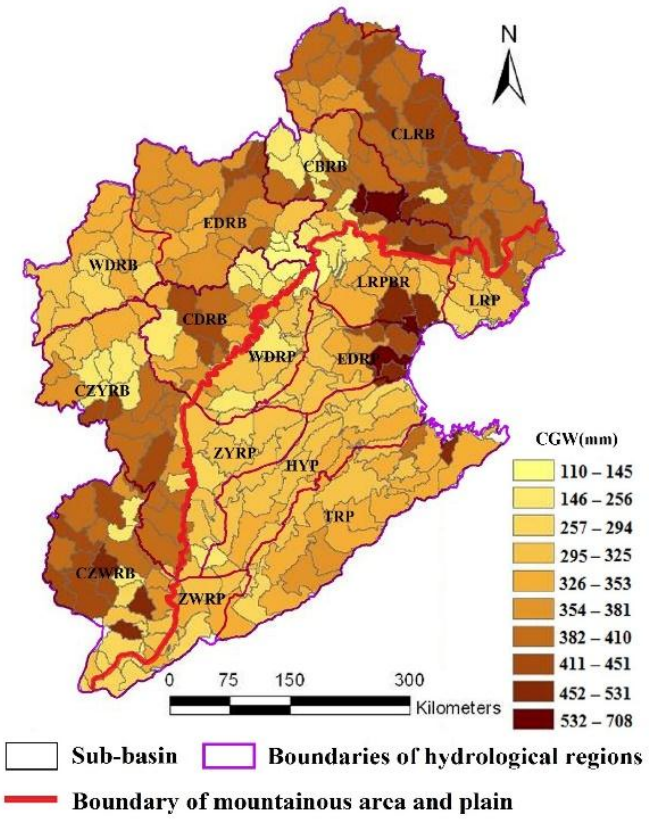

(a)

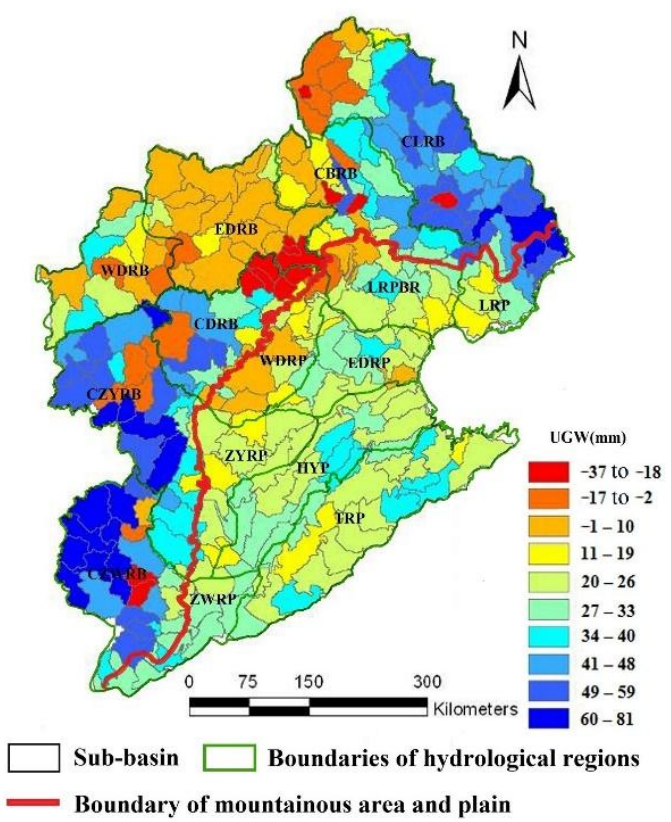

(b)

Figure 8. The spatial distribution of the consumed green water (a) and utilizable green water (b) in HRB. 


\subsubsection{Impacts of Land Use Types on Green Water}

The effective utilization of precipitation (the percentage of precipitation that transforms into green water) varied with land use/cover. The components of annual mean evapotranspiration are shown in Table 7. The efficient evapotranspiration, which equals to CGW, is $106.9 \mathrm{~km}^{3}$ (amounting to $340 \mathrm{~mm}$ ), which accounts for about $70 \%$ of the precipitation or $93 \%$ of the green water. It is much more than the non-utilized green water (NGW) of $7.9 \mathrm{~km}^{3}$ (amount to $25 \mathrm{~mm}$ ). Most of the CGW is in farmlands, woodlands, and grasslands ( $55 \%, 23 \%$ and $22 \%$, respectively.)

Land use types in HRB mainly includes farmlands, woodlands, and grasslands. Table 8 shows the effective utilization of precipitation in those three land use types which demonstrates: (1) the annual averages of effective utilization of precipitation are similar in different land use types; (2) the effective utilization of precipitation in cultivated land is higher than that of grasslands and woodlands for most years; (3) the effective utilization of precipitation is comparatively larger in dry years, especially in 1997, 1999, and 2002, which exceed 80\%, no matter what kind of land use type . In particular, it exceeds $90 \%$ in farmlands.

Table 7. The evapotranspiration (ET) at different land use types in $\operatorname{HRB}\left(\mathrm{km}^{3}\right)$.

\begin{tabular}{cccccccc}
\hline \multirow{2}{*}{ Time } & \multicolumn{5}{c}{ CGW } & \multicolumn{3}{c}{ NGW } & \multirow{2}{*}{ Total ET } & \multirow{2}{*}{ Rainfall } \\
\cline { 2 - 6 } & Farmland & Grassland & Woodland & Urban Area & Water Body & & \\
\hline 1995 & 58.50 & 21.94 & 24.31 & 6.39 & 2.09 & 113.22 & 188.70 \\
1996 & 58.11 & 22.68 & 24.10 & 5.66 & 1.76 & 112.30 & 183.93 \\
1997 & 53.70 & 20.85 & 22.65 & 4.91 & 2.13 & 104.23 & 115.31 \\
1998 & 63.60 & 25.66 & 27.03 & 6.27 & 1.99 & 124.54 & 174.88 \\
1999 & 54.76 & 20.80 & 23.71 & 4.98 & 2.05 & 106.31 & 119.72 \\
2000 & 52.01 & 21.13 & 22.40 & 5.04 & 2.23 & 102.81 & 154.05 \\
2001 & 56.40 & 20.39 & 22.86 & 5.44 & 2.32 & 107.41 & 131.61 \\
2002 & 54.95 & 23.42 & 24.04 & 4.92 & 2.30 & 109.64 & 123.32 \\
2003 & 64.42 & 26.73 & 26.73 & 6.10 & 2.13 & 126.11 & 184.73 \\
2004 & 75.38 & 27.61 & 27.73 & 7.41 & 3.22 & 141.33 & 171.43 \\
Average & 59.18 & 23.12 & 24.56 & 5.71 & 2.22 & 114.79 & 154.77 \\
Percentage (\%) & 51.56 & 20.14 & 21.39 & 4.97 & 1.94 & 100 & \\
\hline
\end{tabular}

Table 8. The effective utilization rate of precipitation in different land use types.

\begin{tabular}{cccccccccc}
\hline \multirow{2}{*}{ Year } & \multicolumn{3}{c}{ Farmland } & \multicolumn{3}{c}{ Grassland } & \multicolumn{3}{c}{ Woodland } \\
\cline { 2 - 10 } & $\mathbf{R}$ & CGW & $\mathbf{P}$ & $\mathbf{R}$ & CGW & $\mathbf{P}$ & $\mathbf{R}$ & CGW & P \\
\hline 1995 & 585.17 & 350.38 & 59.88 & 586.76 & 341.92 & 58.29 & 606.92 & 352.55 & 58.08 \\
1996 & 556.54 & 348.05 & 62.54 & 590.81 & 353.46 & 59.83 & 606.63 & 349.50 & 57.62 \\
1997 & 346.97 & 321.63 & 92.70 & 377.61 & 324.94 & 86.03 & 387.07 & 328.48 & 84.85 \\
1998 & 543.30 & 380.93 & 70.11 & 510.39 & 399.90 & 78.35 & 587.78 & 392.00 & 66.70 \\
1999 & 363.50 & 327.98 & 90.23 & 393.04 & 324.16 & 82.48 & 390.98 & 343.85 & 87.96 \\
2000 & 489.34 & 311.51 & 63.66 & 490.76 & 329.30 & 67.08 & 452.91 & 324.85 & 71.73 \\
2001 & 413.75 & 337.81 & 81.64 & 379.79 & 317.77 & 83.67 & 437.53 & 331.52 & 75.77 \\
2002 & 362.36 & 329.12 & 90.83 & 451.64 & 364.99 & 80.82 & 393.30 & 348.63 & 88.62 \\
2003 & 598.65 & 385.84 & 64.45 & 582.24 & 416.57 & 71.55 & 522.08 & 387.65 & 74.27 \\
2004 & 536.90 & 451.49 & 84.09 & 547.48 & 430.29 & 78.58 & 523.53 & 402.15 & 76.82 \\
Average & 479.65 & 354.47 & 73.90 & 491.05 & 360.33 & 73.38 & 490.87 & 356.12 & 72.55 \\
\hline
\end{tabular}

$\mathrm{R}=$ Rainfall $\left(\mathrm{km}^{3}\right), \mathrm{CGW}=$ consumed green water $\left(\mathrm{km}^{3}\right)$, and $\mathrm{P}=\mathrm{CGW} / \mathrm{R}(\%)$.

\subsubsection{Monthly Variation of Green Water}

The monthly variation of green water in the HRB was analyzed in this section. The annual precipitation in the HRB is $492 \mathrm{~mm}$ during 1995-2004, which is similar to the amount of precipitation $(490 \mathrm{~mm})$ in 2000 . In this case, we selected 2000 as the representative year to analyses the intra-annual changes of green water. The variations of CGW, UGW, and the other main hydrological cycle elements 
are shown in Table 9. The green water, blue water, and the variation of soil water content in 2000 account for $66.8 \%, 28.0 \%$ and $4.8 \%$ of precipitation, respectively. The CGW in HRB kept rising in the first six months while the UGW fell. This is because the consumption of green water by plants was increasing during the transition from the cold season to the warm season. The CGW stays at a relatively high level in July and August, while the UGW is in a rapid growth because of the abundant precipitation of those two months, which accounts for $55 \%$ of the annual precipitation. From September to December, the CGW and UGW in the HRB decreased, while the rate of the latter was relatively low and remained above $35 \mathrm{~mm}$. In this case, improvement of the utilization efficiency of green water can still be explored to increase the CGW and UGW in HRB.

Table 9. The monthly variation of green water resources in 2000 (unit: mm).

\begin{tabular}{ccccccc}
\hline Month & Precipitation & $\boldsymbol{E T}$ & Blue Water & Soil Water Content & CGW & UGW \\
\hline 1 & 8.93 & 2.14 & 0.41 & 94.04 & 1.87 & 14.15 \\
2 & 11.29 & 9.78 & 1.70 & 92.36 & 8.94 & 12.47 \\
3 & 5.73 & 14.41 & 0.48 & 83.05 & 13.53 & 3.14 \\
4 & 11.97 & 18.15 & 0.23 & 77.27 & 16.81 & -2.66 \\
5 & 30.81 & 33.92 & 1.04 & 73.80 & 31.89 & -6.12 \\
6 & 40.47 & 46.78 & 2.51 & 65.81 & 44.41 & -14.14 \\
7 & 148.69 & 64.52 & 49.37 & 97.63 & 59.32 & 17.75 \\
8 & 121.92 & 51.57 & 37.05 & 131.39 & 48.20 & 51.57 \\
9 & 51.54 & 37.35 & 21.13 & 128.98 & 34.84 & 49.16 \\
10 & 45.40 & 26.73 & 14.02 & 134.15 & 24.90 & 54.34 \\
11 & 11.38 & 13.85 & 6.23 & 125.13 & 12.71 & 45.30 \\
12 & 1.58 & 7.95 & 3.03 & 117.29 & 7.25 & 37.45 \\
Total & 489.72 & 327.15 & 137.21 & & 304.66 & \\
\hline
\end{tabular}

\section{Discussion and Conclusions}

\subsection{Discussion}

Green water accounts for $74 \%$ of the mean annual precipitation in the HRB (it is higher in dry years), the proportion is similar in other study areas with a similar climate [17]. Numerous studies have demonstrated that there are positive correlations between the precipitation and green water at both spatial and temporal resolutions [56-58]. Other meteorological factors such as temperature can also have an impact on the green water flow and storage [40]. Besides, land use change can increase or decrease the green water storage [40]. According to the distributions of topography and land use types, the result indicates that green water has a clear spatial pattern. Based on the definition of green water, there must be positive correlation between soil moisture and green water, and this is supported by the spatial pattern of soil moisture in HRB [59]. Therefore, the soil moisture can be used for a quick preliminary estimation of green water with the use of remote sensing technology.

During the operational process of the SWAT model, a land use type will not be regarded as a hydrologic response unit if its area is less than $5 \%$ of the area of a sub-basin. Therefore, in this study, the area of farmland is $3.6 \%$ higher than the value directly obtained from land use data. According to the assessment results, the utilization rate of precipitation in farmlands $(73.90 \%)$ is relatively higher than grasslands $(73.38 \%$ ) and woodlands $(72.55 \%)$. As with the study at Weihe River Basin in northeast China [40], the land use change (an increase of woodland and grassland, a decrease of farmland) leads to the decrease of the green water flow, which supports our results.

Both CGW and UGW have high seasonal variability. The intra-annual distribution of precipitation and the process of plants growth are the dominant factors [60]. Maize and winter wheat are the main crops in the HRB [30], considering their relatively long growth period (2-5 months for maize and 8-10 months for winter wheat), the monthly assessment results of green water have practical significance to guide the agricultural production [61]. 
There are several limitations in this study, one of which is that the land use types in HRB have been divided into five categories broadly. Green water utilization varies among plant types $[9,23]$. Thus, to utilize green water more efficiently, it is necessary to analyze the consumption of green water in different plants (especially between various crops) in the future. The green water in HRB has been analyzed in a ten years period and the change trend of green water in a longer period can be further studied. Furthermore, identifying the impact of climate variability and land use change on green water can give us great insight into the effective utilization of green water. To provide more accurate guidance for the crops with a shorter growth period, the weekly (or even daily) assessment of green water could be further learned with corresponding initial data.

The SWAT model in HRB has been built at a relatively high spatial and temporal resolution with the limited freely available input data. The observed runoff and evapotranspiration data were used for testing the performance of the model; the water balance analysis provides further evidence for the rationality of the simulation results. With this model, several applications such as the variations of green water under different climate/land use scenarios in the past or future could be analyzed with befitting data. However, there are still some shortcuts in this model. For example, during model calibration, only nine hydrological stations were used in the mountain areas and the yearly data were used in plain areas, which may affect the simulation accuracy. Overall, the performance of the model (e.g., the accuracy of outcomes and the minimization of uncertainties) could be enhanced in future studies with the use of more refined datasets.

\subsection{Conclusions}

In this paper, three new indices, including the maximum possible storage of green water (MSGW), the consumed green water (CGW), and the utilizable green water (UGW), are proposed to quantitatively analyze green water use in the Hai River Basin. These indices were applied to the assessment of green water in HRB, their spatial and temporal distributions have been further investigated. The following conclusions are drawn from this study:

(1) Green water is the dominant component of precipitation in the studied area. With the evaluation results of MSGW, CGW and UGW at a sub-basin level, it is feasible to abate the shortage of water by reducing the evapotranspiration in the sub-basins with high CGW and further developing the soil water content in the sub-basins with high UGW.

(2) The distribution of CGW is significantly associated with the distribution of the land use type. Farmland is the main source of CGW in HRB (Table 7); growing low water consuming crops or returning farmland to forests and grasslands deliberately could help to reduce the CGW.

(3) The monthly variate conditions of green water could be obtained from the model. With high accuracy land use data, the efficient utilization patterns of green water could be developed for the different vegetative stages of a specific plant. Model with daily inputs can provide more accurate results because it considers the growth period of a specific plant in detail.

Overall, this paper provided a feasible direction to complement the evaluation system of green water. For the water-deficient area (especially agricultural region), a full valuation of the green water resources could help in turning the proportion of blue and green water back to a reasonable range. Furthermore, our results can be potentially useful for alleviating the contradictions of water demand between the ecosystem and human beings. Additionally, the proper management mode could be prepared in advance for new challenges brought about by climate/land use change.

Author Contributions: K.Z., Y.Z. and F.L. came up with the idea and designed the study; Z.X. and X.S. (Xinyi Song) performed the analyses and wrote the paper; L.L. helped with language editing, and X.S. (Xiaomeng Song) helped in collecting data.

Funding: This research was supported by the National Key Research and Development Program (No. 2016YFC0401301), the Natural Science Foundation of China (No. 51409246 and 51679252), the Jiangsu Province Natural Science Foundation (No. BK20130178), and the Open Research Fund of State Key Laboratory of 
Simulation and Regulation of Water Cycle in River Basin (China Institute of Water Resources and Hydropower Research) (No. IWHR-SKL-201603).

Acknowledgments: Thanks to editor and reviewers for their constructive comments and suggestions, which greatly help to improve the quality of our article. We would also like to thank Ravi Jain for his help to improve the English in our article.

Conflicts of Interest: The authors declare no conflict of interest.

\section{References}

1. Mooney, H.; Cropper, A.; Reid, W. Confronting the human dilemma. Nature 2005, 434, 561-562. [CrossRef] [PubMed]

2. Oki, T.; Kanae, S. Global hydrological cycles and world water resources. Science 2006, 313, $1068-1072$. [CrossRef] [PubMed]

3. Falkenmark, M. Land-Water Linkages: A Synopsis: Land and Water Integration and River Basin Management; Land and Water Bulletin No. 1; FAO: Rome, Italy, 1995; pp. 15-17.

4. Schyns, J.F.; Hoekstra, A.Y.; Booij, M.J. Review and classification of indicators of green water availability and scarcity. Hydrol. Earth Syst. Sci. 2015, 12, 4581-4608. [CrossRef]

5. Rockström, J. Green water security for the food makers of tomorrow: Windows of opportunity in drought-prone savannahs. Water Sci. Technol. 2001, 43, 71-78. [CrossRef] [PubMed]

6. Gordon, L.J.; Finlayson, C.M.; Falkenmark, M.; Molden, D.; De Fraiture, C. Managing water in agriculture for food production and other ecosystem services. Agric. Water Manag. 2010, 97, 512-519. [CrossRef]

7. Vanham, D. A holistic water balance of Austria-How does the quantitative proportion of urban water requirements relate to other users? Water Sci. Technol. 2012, 66, 549-555. [CrossRef] [PubMed]

8. Cosgrove, W.J.; Rijsberman, F.R. Challenge for the 21st century: Making water everybody's business. Sustain. Dev. Int. 2000, 2, 149-156.

9. Hoekstra, A.Y.; Mekonnen, M.M. The water footprint of humanity. Proc. Natl. Acad. Sci. USA 2012, 109, 3232-3237. [CrossRef] [PubMed]

10. Rockström, J. On-farm green water estimates as a tool for increased food production in water scarce regions. Phys. Chem. Earth 1999, 24, 375-383. [CrossRef]

11. Falkenmark, M.; Rockström, J. The new blue and green water paradigm: Breaking new ground for water resources planning and management. J. Water Resour. Plan. Manag. 2006, 132, 129-132. [CrossRef]

12. Xia, Z.Q.; Li, Q.F. Study on soil water resource and its evaluating methodology. Adv. Water Sci. 2001, 12, 535-540. (In Chinese)

13. Wang, H.; Yang, G.Y.; Jia, Y.W.; Wang, J.H. Connotation and assessment index system of soil water resources. J. Hydraul. Eng. 2006, 37, 389-394. (In Chinese)

14. Gerten, D.; Hoff, H.; Bondeau, A.; Lucht, W.; Smith, P.; Zaehle, S. Contemporary "green" water flows: Simulations with a dynamic global vegetation and water balance model. Phys. Chem. Earth 2005, 30, 334-338. [CrossRef]

15. Zhao, A.Z.; Zhu, X.F.; Chen, S.C.; Li, M. Trend analysis for blue and green water resources in the Weihe River basin of Northwest China during the past thirty years and in the near future. In Proceedings of the International Conference on Agro-Geoinformatics, Beijing, China, 11-14 August 2014; pp. 1-5.

16. Konar, M.; Dalin, C.; Hanasaki, N.; Rinaldo, A.; Rodriguez-Iturbe, I. Temporal dynamics of blue and green virtual water trade networks. Water Resour. Res. 2012, 48, 2360-2368. [CrossRef]

17. Zhang, W.; Zha, X.; Li, J.; Liang, W.; Ma, Y.; Fan, D.; Li, S. Spatiotemporal change of blue water and green water resources in the headwater of yellow river basin, China. Water Resour. Manag. 2014, 28, 4715-4732. [CrossRef]

18. Hanasaki, N.; Inuzuka, T.; Kanae, S.; Oki, T.; Hoff, H.; Falkenmark, M. An estimation of global virtual water flow and sources of water withdrawal for major crops and livestock products using a global hydrological model. J. Hydrol. 2010, 384, 232-244. [CrossRef]

19. Hoff, H.; Falkenmark, M.; Gerten, D.; Gordon, L.; Karlberg, L.; Rockström, J. Greening the global water system. J. Hydrol. 2010, 384, 177-186. [CrossRef] 
20. Jewitt, G.P.W.; Garratt, J.A.; Calder, I.R.; Fuller, L. Water resources planning and modelling tools for the assessment of land use change in the Luvuvhu catchment, South Africa. Phys. Chem. Earth 2004, 29, 1233-1241. [CrossRef]

21. Cao, X.C.; Wu, P.T.; Wang, Y.B.; Zhao, X.N. Assessing blue and green water utilisation in wheat production of China from the perspectives of water footprint and total water use. Hydrol. Earth Syst. Sci. 2014, 18, 3165-3178. [CrossRef]

22. Quinteiro, P.; Dias, A.C.; Silva, M.; Ridoutt, B.G.; Arroja, L. A contribution to the environmental impact assessment of green water flows. J. Clean. Prod. 2015, 93, 318-329. [CrossRef]

23. Zoumides, C.; Bruggeman, A.; Hadjikakou, M.; Zachariadis, T. Policy-relevant indicators for semi-arid nations: The water footprint of crop production and supply utilization of cyprus. Ecol. Indic. 2014, 43, 205-214. [CrossRef]

24. Gobin, A.; Kersebaum, K.C.; Eitzinger, J.; Trnka, M.; Hlavinka, P.; Takáč, J.; Kroes, J.; Ventrella, D.; Marta, A.D.; Deelstra, J.; Lalić, B. Variability in the water footprint of arable crop production across European regions. Water 2017, 9, 93. [CrossRef]

25. Bulcock, H.H.; Gush, M.B.; Jewitt, G.P.W. A comparison of productive and non-productive green water-use efficiency of Podocarpus henkelii and Pinus patula in the Kwazulu-natal midlands. South. For. J. For. Sci. 2014, 76, 75-84.

26. Willaarts, B.A.; Volk, M.; Aguilera, P.A. Assessing the ecosystem services supplied by freshwater flows in mediterranean agroecosystems. Agric. Water Manag. 2012, 105, 21-31. [CrossRef]

27. Schuol, J.; Abbaspour, K.C.; Yang, H.; Srinivasan, R.; Zehnder, A.J.B. Modeling blue and green water availability in Africa. Water Resour. Res. 2008, 44, 212-221. [CrossRef]

28. Sposito, G. Green water and global food security. Vadose Zone J. 2013, 12, 1742-1751. [CrossRef]

29. Stewart, B.A.; Peterson, G.A. Managing green water in dryland agriculture. Agron. J. 2015, 107, $1544-1553$. [CrossRef]

30. Water Resources Bulletin of the Hai River Basin. Available online: http://www.hwcc.gov.cn/hwcc/static/ szygb/hhlyszygb.htm (accessed on 20 October 2017).

31. Wang, Z.G.; Luo, Y.Z.; Zhu, X.J.; Rui, W.; Li, W.; Zhang, M.H. Watershed modeling of surface water-groundwater interaction under projected climate change and water management in the Haihe river basin, China. Br. J. Environ. Clim. Chang. 2013, 3, 421-443. [CrossRef]

32. Xia, J.; Qiu, B.; Li, Y.Y. Water resources vulnerability and adaptive management in the Huang, Huai and Hai River basins of China. Water Int. 2012, 37, 523-536. [CrossRef]

33. Zhang, D.D.; Yan, D.H.; Wang, Y.C.; Lu, F.; Wu, D. Changes in extreme precipitation in the huang-huai-hai river basin of China during 1960-2010. Theor. Appl. Climatol. 2015, 120, 195-209. [CrossRef]

34. Yan, D.; Xu, T.; Girma, A.; Yuan, Z.; Weng, B.; Qin, T. Regional correlation between precipitation and vegetation in the Huang-Huai-Hai River Basin, China. Water 2017, 9, 557. [CrossRef]

35. Ren, X.S.; Hu, Z.L.; Cao, Y.B.; He, S. Water Resources Assessment in the Haihe River Basin; Water Resources and Electricity Press: Beijing, China, 2007. (In Chinese)

36. Shi, X.Z.; Yu, D.S.; Warner, E.D.; Pan, X.Z.; Petersen, G.W.; Gong, Z.G. Soil database of 1:1,000,000 digital soil survey and reference system of the Chinese genetic soil classification system. Soil Surv. Horiz. 2004, 45, 129. [CrossRef]

37. Wei, H.B.; Zhang, Z.P.; Yang, J.P. Establishing method for soil database of SWAT model. Water Resour. Hydropower Eng. 2007, 38, 15-18. (In Chinese)

38. Saxton, K.E. Soil Water Characteristics Hydraulic Properties Calculator. USDA-Agricultural Research Service in Cooperation with Department of Biological Systems Engineering, Washington State University, Pullman, WA. Available online: http:/ / hydrolab.arsusda.gov/soilwater/Index.htm (accessed on 9 March 2018).

39. Standardization Administration of China. Current Land Use Condition Classification. In China's National Standard (GB/T21010-2007); Standards Press of China: Beijing, China, 2007.

40. Zhao, A.; Zhu, X.; Liu, X.; Pan, Y.; Zuo, D. Impacts of land use change and climate variability on green and blue water resources in the Weihe river basin of northwest China. Catena 2016, 137, 318-327. [CrossRef]

41. Neitsch, S.L.; Arnold, J.G.; Kiniry, J.R.; Srinivasan, R.; Williams, J.R. Soil and water assessment tool user's manual version 2000. In GSWRL Report 202; Texas Water Resources Institute: College Station, TX, USA, 2002.

42. Van Orshoven, J.; Coppens, J.; Terres, J.M. Possibilities and limitations of avswat2000 for the assessment of environmental impacts of farming practices. Int. J. Climatol. 2007, 32, 261-273. 
43. Zhang, Q.L.; Chen, Y.X.; Jilani, G.; Shamsi, I.H.; Yu, Q.G. Model avswat apropos of simulating non-point source pollution in Taihu lake basin. J. Hazard. Mater. 2010, 174, 824. [CrossRef] [PubMed]

44. Arnold, J.G.; Moriasi, D.N.; Gassman, P.W.; Abbaspour, K.C.; White, M.J.; Srinivasan, R.; Santhi, C.; Harmel, R.D.; Van Griensven, A.; Van Liew, M.W.; et al. SWAT: Model use, calibration, and validation. Trans. ASABE 2012, 55, 1345-1352. [CrossRef]

45. Luo, Y.; Zhang, X.; Liu, X.; Ficklin, D.; Zhang, M. Dynamic modeling of organophosphate pesticide load in surface water in the northern San Joaquin valley watershed of California. Environ. Pollut. 2008, 156, 1171-1181. [CrossRef] [PubMed]

46. Neitsch, S.L.; Arnold, J.G.; Kiniry, J.R.; Williams, J.R. Soil E Water Assessment Tool; Theoretical Documentation Version 2009; Texas Water Resources Institute Technical Report No. 406; Texas A\&M University System: College Station, TX, USA, 2011.

47. Zhao, Y.; Liu, X.; Zhong, X.; Cao, J.; Ren, T.; Feng, D. Determination of soil depth and its water threshold for diagnosing water deficit of winter wheat based on grain yield. Trans. Chin. Soc. Agric. Eng. 2014, 30, 147-154. (In Chinese)

48. Xue, C.; Liu, R.; Ma, Z. Drought grade classification of summer maize in Huang-Huai-Hai area. Trans. Chin. Soc. Agric. Eng. 2014, 30, 147-156. (In Chinese)

49. Sun, C.; Ren, L. Assessment of surface water resources and evapotranspiration in the Haihe river basin of China using swat model. Hydrol. Process. 2013, 27, 1200-1222. [CrossRef]

50. Abbaspour, K.C.; Johnson, C.A.; Genuchten, M.T.V. Estimating uncertain flow and transport parameters using a sequential uncertainty fitting procedure. Vadose Zone J. 2004, 3, 1340-1352. [CrossRef]

51. Nash, J.E.; Sutcliffe, J.V. River flow forecasting through conceptual models-part1-A discussion of principles. J. Hydrol. 1970, 10, 282-290. [CrossRef]

52. Moriasi, D.N.; Arnold, J.G.; Van Liew, M.W.; Bingner, R.L.; Harmel, R.D.; Veith, T.L. Model evaluation guidelines for systematic quantification of accuracy in watershed simulations. Trans. ASABE 2007, 50, 885-900. [CrossRef]

53. Abbaspour, K.C.; Rouholahnejad, E.; Vaghefi, S.; Srinivasan, R.; Yang, H.; Kløve, B. A continental-scale hydrology and water quality model for Europe: Calibration and uncertainty of a high-resolution large-scale SWAT model. J. Hydrol. 2015, 524, 733-752. [CrossRef]

54. Wu, B.; Yan, N.; Xiong, J.; Bastiaanssen, W.G.M.; Zhu, W.; Stein, A. Validation of ETWatch using field measurements at diverse landscapes: A case study in Hai Basin of China. J. Hydrol. 2012, 436-437, 67-80. [CrossRef]

55. Xiong, J.; Wu, B.; Yan, N.; Zeng, Y.; Liu, S. Estimation and validation of land surface evaporation using remote sensing and meteorological data in north China. IEEE J. Sel. Top. Appl. Earth Obs. Remote Sens. 2010, 3, 337-344. [CrossRef]

56. Zang, C.F.; Liu, J.; Velde, M.V.D.; Kraxner, F. Assessment of spatial and temporal patterns of green and blue water flows in inland river basins in northwest China. Hydrol. Earth Syst. Sci. 2012, 16, 2859-2870. [CrossRef]

57. Zang, C.F.; Liu, J.G. Trend analysis for the flows of green and blue water in the Heihe River basin, northwestern China. J. Hydrol. 2013, 502, 27-36. [CrossRef]

58. Rouholahnejad, E.; Abbaspour, K.C.; Srinivasan, R.; Bacu, V.; Lehmann, A. Water resources of the Black Sea Basin at high spatial and temporal resolution. Water Resour. Res. 2014, 50, 5866-5885. [CrossRef]

59. Moiwo, J.P.; Yang, Y.H.; Han, S.M.; Lu, W.X.; Yan, N.N.; Wu, B.F. A method for estimating soil moisture storage in regions under water stress and storage depletion: A case study of Hai River Basin, North China. Hydrol. Process. 2011, 25, 2275-2287. [CrossRef]

60. Liu, J.G.; Yang, H. Spatially explicit assessment of global consumptive water uses in cropland: Green and blue water. J. Hydrol. 2010, 384, 187-197. [CrossRef]

61. Liu, S.M.; Xu, Z.W.; Zhu, Z.L.; Jia, Z.Z.; Zhu, M.J. Measurements of evapotranspiration from eddy-covariance systems and large aperture scintillometers in the Hai river basin, China. J. Hydrol. 2013, 487, 24-38. [CrossRef]

(C) 2018 by the authors. Licensee MDPI, Basel, Switzerland. This article is an open access article distributed under the terms and conditions of the Creative Commons Attribution (CC BY) license (http://creativecommons.org/licenses/by/4.0/). 